\title{
Ethanol Vehicle and Infrastructure Codes and Standards Citations
}

This document lists codes and standards typically used for U.S. ethanol vehicle and infrastructure projects. To determine which codes and standards apply to a specific project, identify the codes and standards currently in effect within the jurisdiction where the project will be located. Some jurisdictions also have unique ordinances or regulations that could apply.

Learn about codes and standards basics at www.afdc.energy.gov/afdc/codes_standards_basics.html.

Find ethanol vehicle and infrastructure codes and standards in these categories:

- Definition and Classification of Liquids

- Fire Prevention and Fire Risk Control

- Building Construction Requirements

- Electrical Systems

- Storage of Liquids

- $\quad$ Storage of Liquids in Containers

- Industrial Occupancies

- Storage Occupancies

- Detached, Unprotected Buildings

- Outdoor Storage

- $\quad$ Automatic Fire Protection for Inside Liquid Storage Areas

- Storage of Liquids in Tanks

○ Requirements for All Tanks

- Aboveground Storage Tanks

- Underground Tanks

- Storage Tank Buildings

- Storage Tank Vaults

- Processing Facilities

- Dispensing, Handling, Transfer, and Use of Liquids

- Operational Requirements

- Piping for Liquids

- Vapor Processing and Vapor Recovery Systems for Liquid Motor Fuels

- Farms and Remote Sites

- $\underline{\text { Vehicle }}$

\section{Definition and Classification of Liquids}

Scope

- $\quad$ NFPA 30, Flammable and Combustible Liquids Code, 4.1

\section{Definitions}

- NFPA 30, Flammable and Combustible Liquids Code, 4.2

- ASTM Standard Test Methods 


\section{Classification of Liquids}

- $\quad$ NFPA 30, Flammable and Combustible Liquids Code, 4.3

- ASTM Standard Test Methods

\section{Determination of Flash Point}

- $\quad$ NFPA 30, Flammable and Combustible Liquids Code, 4.4

- ASTM Standard Test Methods

\section{Relationship to Other Classification Systems}

- $\quad$ NFPA 30, Flammable and Combustible Liquids Code, 4.5

\section{Fire Prevention and Fire Risk Control}

\section{Scope}

- $\quad$ NFPA 30, Flammable and Combustible Liquids Code, 6.1

\section{Definitions}

- $\quad$ NFPA 30, Flammable and Combustible Liquids Code, 6.2

\section{Management of Fire and Explosion Hazards}

- NFPA 30, Flammable and Combustible Liquids Code, 6.3

- NFPA 69, Standard on Explosion Prevention Systems

- NFPA 68, Standard on Explosion Protection by Deflagration Venting

\section{Hazards Analysis}

- $\quad$ NFPA 30, Flammable and Combustible Liquids Code, 6.4

\section{Control of Ignition Sources}

- NFPA 30, Flammable and Combustible Liquids Code, 6.5

- $\quad$ NFPA 51B, Standard for Fire Prevention During Welding, Cutting, and Other Hot Work

- NFPA 77, Recommended Practice on Static Electricity

\section{Detection and Alarm Systems}

- $\quad$ NFPA 30, Flammable and Combustible Liquids Code, 6.6

- NFPA 72, National Fire Alarm Code

\section{Fire Protection and Suppression Systems}

- $\quad$ NFPA 30, Flammable and Combustible Liquids Code, 6.7

- NFPA 24, Standard for the Installation of Private Fire Service Mains and Their Appurtenances

- NFPA 13, Standard for the Installation of Sprinkler Systems

- NFPA 10, 11, 12, 12A, 14, 15, 16, 17, 2001

\section{Emergency Planning and Training}

- $\quad$ NFPA 30, Flammable and Combustible Liquids Code, 6.8 
Inspection and Maintenance

- $\quad$ NFPA 30, Flammable and Combustible Liquids Code, 6.9

- NFPA 25, Standard for the Inspection, Testing, and Maintenance of Water-Based Fire Protection Systems

Management of Security

- NFPA 30, Flammable and Combustible Liquids Code, 6.10

\section{Building Construction Requirements}

\section{Scope}

- NFPA 30A, Code for Motor Fuel Dispensing Facilities and Repair Garages, 7.1

\section{General Requirements}

- $\quad$ NFPA 30A, Code for Motor Fuel Dispensing Facilities and Repair Garages, 7.2

\section{Motor Fuel Dispensing Facilities}

- $\quad$ NFPA 30A, Code for Motor Fuel Dispensing Facilities and Repair Garages, 7.3

- NFPA 101, Life Safety Code

- NFPA 220, Standard on Types of Building Construction

- NFPA 80, Standard for Fire Doors and Other Opening Protectives

- NFPA 91, Standard for Exhaust Systems for Air Conveying of Vapors, Gases, Mists, and Noncombustible Particulate Solids

\section{Repair Garages}

- $\quad$ NFPA 30A, Code for Motor Fuel Dispensing Facilities and Repair Garages, 7.4

- NFPA 101, Life Safety Code

- NFPA 13, Standard for the Installation of Sprinkler Systems

- NFPA 90A, Standard for the Installation of Air-Conditioning and Ventilation Systems

\section{Heating, Ventilation, and Air-Conditioning}

- NFPA 30A, Code for Motor Fuel Dispensing Facilities and Repair Garages, 7.5

\section{Heat-Producing Appliances}

- $\quad$ NFPA 30A, Code for Motor Fuel Dispensing Facilities and Repair Garages, 7.6

\section{Dynamic Automotive Emissions Testing Equipment}

- $\quad$ NFPA 30A, Code for Motor Fuel Dispensing Facilities and Repair Garages, 7.7

\section{Electrical Systems}

\section{Scope}

- $\quad$ NFPA 30A, Code for Motor Fuel Dispensing Facilities and Repair Garages, 8.1

- $\quad$ NFPA 30, Flammable and Combustible Liquids Code, 7.1 


\section{Definitions}

- $\quad$ NFPA 30, Flammable and Combustible Liquids Code, 7.2

\section{General Requirements}

- $\quad$ NFPA 30A, Code for Motor Fuel Dispensing Facilities and Repair Garages, 8.2

- $\quad$ NFPA 30, Flammable and Combustible Liquids Code, 7.3

- NFPA 70, National Electric Code

- NFPA 497, Recommended Practice for the Classification of Flammable Liquids, Gases, or Vapors and of Hazardous Locations for Electrical Installations in Chemical Process Areas

- NFPA 496, Standard for Purged and Pressurized Enclosures for Electrical Equipment Installation in Classified Locations

- NFPA 30A, Code for Motor Fuel Dispensing Facilities and Repair Garages, 8.3

\section{Emergency Electrical Disconnects}

- $\quad$ NFPA 30A, Code for Motor Fuel Dispensing Facilities and Repair Garages, 8.4

\section{Specific Requirements for Marine Fuel Facilities}

- $\quad$ NFPA 30A, Code for Motor Fuel Dispensing Facilities and Repair Garages, 8.5

\section{Storage of Liquids}

\section{Scope}

- $\quad$ NFPA 30A, Code for Motor Fuel Dispensing Facilities and Repair Garages, 4.1

- $\quad$ NFPA 30, Flammable and Combustible Liquids Code, 9.1

\section{Definitions}

- $\quad$ NFPA 30, Flammable and Combustible Liquids Code, 9.2

\section{General Requirements}

- $\quad$ NFPA 30A, Code for Motor Fuel Dispensing Facilities and Repair Garages, 4.2

- $\quad$ NFPA 30, Flammable and Combustible Liquids Code, 9.3

\section{Storage of Liquids}

- NFPA 30A, Code for Motor Fuel Dispensing Facilities and Repair Garages, 4.3

- UL 2245, Standard for Below-Grade Vaults for Flammable Liquid Storage Tanks

- NFPA 91, Standard for Exhaust Systems for Air Conveying of Vapors, Gases, Mists, and Noncombustible Particulate Solids

- UL 2080, Standard for Fire Resistant Tanks for Flammable and Combustible Liquids

- UL 2085, Standards for Protected Aboveground Tanks for Flammable and Combustible Liquids

- STI Corrosion Control Standards 


\section{Acceptable Containers}

- $\quad$ NFPA 30, Flammable and Combustible Liquids Code, 9.4

- ASTM Standards for Containers

- ANSI/UL Standards for Containers

- US DOT 10CFR49

\section{Flammable Liquids Storage Cabinets}

- $\quad$ NFPA 30, Flammable and Combustible Liquids Code, 9.5

- NFPA 251, Standard Methods of Tests of Fire Resistance of Building Construction and Materials

- NFPA 91, Standard for Exhaust Systems for Air Conveying of Vapors, Gases, Mists, and Noncombustible Particulate Solids

\section{Maximum Allowable Quantities (MAQs) per Control Area}

- $\quad$ NFPA 30, Flammable and Combustible Liquids Code, 9.6

\section{Control Areas}

- $\quad$ NFPA 30, Flammable and Combustible Liquids Code, 9.7

\section{Classification of Occupancies That Exceed the MAQs of Liquids per Control Area}

- $\quad$ NFPA 30, Flammable and Combustible Liquids Code, 9.8

- NFPA 5000, Building Construction and Safety Code

- ICC International Building Code

\section{Construction Requirements}

- $\quad$ NFPA 30, Flammable and Combustible Liquids Code, 9.9

- NFPA 251, Standard Methods of Tests of Fire Resistance of Building Construction and Materials

- $\quad$ NFPA 80, Standard for Fire Doors and Other Opening Protectives

\section{Fire Protection}

- $\quad$ NFPA 30, Flammable and Combustible Liquids Code, 9.10

- NFPA 10, Standard for Portable Fire Extinguishers

- NFPA 13, Standard for the Installation of Sprinkler Systems

- NFPA 14, Standard for the Installation of Standpipe and Hose Systems

\section{Electrical Systems}

- NFPA 30, Flammable and Combustible Liquids Code, 9.12

\section{Containment, Drainage, and Spill Control}

- $\quad$ NFPA 30, Flammable and Combustible Liquids Code, 9.13

\section{Ventilation}

- $\quad$ NFPA 30, Flammable and Combustible Liquids Code, 9.14

\section{Explosion Control}

- $\quad$ NFPA 30, Flammable and Combustible Liquids Code, 9.16 
- NFPA 68, Standard on Explosion Protection by Deflagration Venting

Separation from Incompatible Materials

- NFPA 30, Flammable and Combustible Liquids Code, 9.17

Dispensing, Handling, and Use of Liquids in Storage Areas

- NFPA 30, Flammable and Combustible Liquids Code, 9.18

\section{Outdoor Storage of Liquids}

- $\quad$ NFPA 30, Flammable and Combustible Liquids Code, 9.19

\section{Storage of Liquids in Containers}

\section{Industrial Occupancies}

Scope

- $\quad$ NFPA 30, Flammable and Combustible Liquids Code, 11.1

\section{Definitions}

- NFPA 30, Flammable and Combustible Liquids Code, 11.2

General Requirements

- $\quad$ NFPA 30, Flammable and Combustible Liquids Code, 11.3

\section{Storage Occupancies}

Scope

- NFPA 30, Flammable and Combustible Liquids Code, 12.1

\section{Definitions}

- NFPA 30, Flammable and Combustible Liquids Code, 12.2

\section{General Requirements}

- $\quad$ NFPA 30, Flammable and Combustible Liquids Code, 12.3

- NFPA 13, Standard for the Installation of Sprinkler Systems

Maximum Allowable Quantities and Maximum Storage Heights

- $\quad$ NFPA 30, Flammable and Combustible Liquids Code, 12.6

\section{Control Areas}

- $\quad$ NFPA 30, Flammable and Combustible Liquids Code, 12.7

General Purpose Warehouse Storing Liquids in Quantities not exceeding $M A Q$

- $\quad$ NFPA 30, Flammable and Combustible Liquids Code, 12.8

\section{Construction Requirements}

- $\quad$ NFPA 30, Flammable and Combustible Liquids Code, 12.9

Fire Protection

- NFPA 30, Flammable and Combustible Liquids Code, 12.10

\section{Emergency Control Systems}

- NFPA 30, Flammable and Combustible Liquids Code, 12.11 


\section{Electrical Systems}

- NFPA 30, Flammable and Combustible Liquids Code, 12.12

\section{Containment, Drainage, and Spill Control}

- NFPA 30, Flammable and Combustible Liquids Code, 12.13

\section{Ventilation}

- NFPA 30, Flammable and Combustible Liquids Code, 12.14

\section{Exhausted Enclosures}

- NFPA 30, Flammable and Combustible Liquids Code, 12.15

\section{Explosion Control}

- NFPA 30, Flammable and Combustible Liquids Code, 12.16

\section{Separation from Incompatible Materials}

- NFPA 30, Flammable and Combustible Liquids Code, 12.17

Dispensing, Handling, and Use of Liquids in Storage Occupancies

- NFPA 30, Flammable and Combustible Liquids Code, 12.18

\section{Outdoor Storage of Liquids}

- NFPA 30, Flammable and Combustible Liquids Code, 12.19

\section{Detached, Unprotected Buildings}

- NFPA 30, Flammable and Combustible Liquids Code, 13

\section{Scope}

- NFPA 30, Flammable and Combustible Liquids Code, 13.1

\section{Definitions}

- NFPA 30, Flammable and Combustible Liquids Code, 13.2

\section{General Requirements}

- $\quad$ NFPA 30, Flammable and Combustible Liquids Code, 13.3

- NFPA 13, Standard for the Installation of Sprinkler Systems

Maximum Allowable Quantities and Maximum Storage Heights

- NFPA 30, Flammable and Combustible Liquids Code, 13.6

\section{Control Areas}

- $\quad$ NFPA 30, Flammable and Combustible Liquids Code, 13.7

\section{Construction Requirements}

- $\quad$ NFPA 30, Flammable and Combustible Liquids Code, 13.9

\section{Fire Protection}

- $\quad$ NFPA 30, Flammable and Combustible Liquids Code, 13.1

\section{Emergency Control Systems}

- NFPA 30, Flammable and Combustible Liquids Code, 13.11

\section{Electrical Systems}

- $\quad$ NFPA 30, Flammable and Combustible Liquids Code, 13.12 
Containment, Drainage, and Spill Control

- NFPA 30, Flammable and Combustible Liquids Code, 13.13

Ventilation

- NFPA 30, Flammable and Combustible Liquids Code, 13.14

Exhausted Enclosures

- NFPA 30, Flammable and Combustible Liquids Code, 13.15

\section{Explosion Control}

- NFPA 30, Flammable and Combustible Liquids Code, 13.16

Separation from Incompatible Materials

- $\quad$ NFPA 30, Flammable and Combustible Liquids Code, 13.17

Dispensing, Handling, and Use of Liquids in Detached, Unprotected Buildings

- NFPA 30, Flammable and Combustible Liquids Code, 13.18

\section{Outdoor Storage of Liquids}

- $\quad$ NFPA 30, Flammable and Combustible Liquids Code, 13.19

\section{Outdoor Storage}

- $\quad$ NFPA 30, Flammable and Combustible Liquids Code, 15

\section{Scope}

- NFPA 30, Flammable and Combustible Liquids Code, 15.1

\section{Definitions}

- NFPA 30, Flammable and Combustible Liquids Code, 15.2

\section{General Requirements}

- NFPA 30, Flammable and Combustible Liquids Code, 15.3

\section{Outdoor Storage Adjacent to a Building}

- $\quad$ NFPA 30, Flammable and Combustible Liquids Code, 15.4

\section{Automatic Fire Protection for Inside Liquid Storage Areas}

\section{Scope}

- $\quad$ NFPA 30, Flammable and Combustible Liquids Code, 16.1

\section{Definitions}

- NFPA 30, Flammable and Combustible Liquids Code, 16.2

\section{General Requirements}

- NFPA 30, Flammable and Combustible Liquids Code, 16.3

\section{Automatic Sprinkler and Foam-Water Sprinkler Fire Protection Systems}

- $\quad$ NFPA 30, Flammable and Combustible Liquids Code, 16.4 
- NFPA 16, Standard for the Installation of Foam-Water Sprinkler and Foam-Water Spray Systems

- NFPA 25, Standard for the Inspection, Testing, and Maintenance of Water-Based Fire Protection Systems

Fire Protection System Design Criteria

- NFPA 30, Flammable and Combustible Liquids Code, 16.5

- NFPA 13, Standard for the Installation of Sprinkler Systems

- NFPA 16, Standard for the Installation of Foam-Water Sprinkler and Foam-Water Spray Systems

- UL 2368, Standard for Fire Exposure Testing of Intermediate Bulk Containers for Flammable and Combustible Liquids

Fire Projection System Design Schemes

- $\quad$ NFPA 30, Flammable and Combustible Liquids Code, 16.6

- NFPA 13, Standard for the Installation of Sprinkler Systems

Water Supply

- $\quad$ NFPA 30, Flammable and Combustible Liquids Code, 16.7

\section{Containment, Drainage, and Spill Control}

- $\quad$ NFPA 30, Flammable and Combustible Liquids Code, 16.8

- NFPA 15, Standard for Water Spray Fixed Systems for Fire Protection

\section{Other Automatic Fire Protection Systems}

- $\quad$ NFPA 30, Flammable and Combustible Liquids Code, 16.9

\section{Storage of Liquids in Tanks}

\section{Requirements for All Tanks}

Scope

- $\quad$ NFPA 30, Flammable and Combustible Liquids Code, 21.1

\section{Definitions}

- $\quad$ NFPA 30, Flammable and Combustible Liquids Code, 21.2

\section{General Requirements}

- $\quad$ NFPA 30, Flammable and Combustible Liquids Code, 21.3

\section{Design and Construction of Storage Tanks}

- $\quad$ NFPA 30, Flammable and Combustible Liquids Code, 21.4

- API Tank Specifications

- UL Tank Standards

- ANSI Tank Standards

- ASME Code for Unfired Pressure Vessels 
- ASME Boiler and Pressure Vessel Code

- API Standard 2000, Venting Atmospheric and Low-Pressure Storage Tanks

- NFPA 69, Standard on Explosion Prevention Systems

- NFPA 77, Recommended Practice on Static Electricity

\section{Testing Requirements for Tanks}

- $\quad$ NFPA 30, Flammable and Combustible Liquids Code, 21.5

- API 653, Tank Inspection, Repair, Alteration, and Reconstruction

Fire Prevention and Control

- $\quad$ NFPA 30, Flammable and Combustible Liquids Code, 21.6

- NFPA 25, Standard for the Inspection, Testing, and Maintenance of Water-Based Fire Protection Systems

\section{Operation of Storage Tanks}

- $\quad$ NFPA 30, Flammable and Combustible Liquids Code, 21.7

- API 2350, Overfill Protection for Storage Tanks in Petroleum Facilities

- NFPA 704, Standard System for the Identification of the Hazards of Materials for Emergency Response

- NFPA 326, Standard for the Safeguarding of Tanks and Containers for Entry, Cleaning, or Repair

- API Tank Cleaning Specifications

- NFPA 329, Recommended Practice for Handling Releases of Flammable and Combustible Liquids and Gases

Inspection and Maintenance of Storage Tanks and Storage Tank Appurtenances

- $\quad$ NFPA 30, Flammable and Combustible Liquids Code, 21.8

- API 653, Tank Inspection, Repair, Alteration, and Reconstruction

- API 2350, Overfill Protection for Storage Tanks in Petroleum Facilities

- API 12R1, Setting, Maintenance, Inspection, Operation, and Repair of Tanks in Production Service

- STI SP001, Standard for Inspection of Aboveground Storage Tanks

\section{Aboveground Storage Tanks}

Scope

- $\quad$ NFPA 30, Flammable and Combustible Liquids Code, 22.1

\section{Definitions}

- $\quad$ NFPA 30, Flammable and Combustible Liquids Code, 22.2

\section{Location of Aboveground Storage Tanks}

- $\quad$ NFPA 30, Flammable and Combustible Liquids Code, 22.4 
- PEI RP200, Recommended Practices for Installation of Aboveground Storage Systems for Motor Vehicle Fueling

Installation of Aboveground Storage Tanks

- $\quad$ NFPA 30, Flammable and Combustible Liquids Code, 22.5

- API 650, Welded Steel Tanks for Oil Storage

Vent Piping for Aboveground Tanks

- $\quad$ NFPA 30, Flammable and Combustible Liquids Code, 22.6

Emergency Relief Venting for Fire Exposure for Aboveground Storage Tanks

- $\quad$ NFPA 30, Flammable and Combustible Liquids Code, 22.7

Fire Protection for Aboveground Storage Tanks

- $\quad$ NFPA 30, Flammable and Combustible Liquids Code, 22.8

- NFPA 11, 15, and 69

- UL 2080, Standard for Fire Resistant Tanks for Flammable and Combustible Liquids

Additional Requirements for Fire-Resistant Aboveground Storage Tanks

- $\quad$ NFPA 30, Flammable and Combustible Liquids Code, 22.9

Additional Requirements for Protected Aboveground Storage Tanks

- NFPA 30, Flammable and Combustible Liquids Code, 22.10

- UL 2085, Standards for Protected Aboveground Tanks for Flammable and Combustible Liquids

Control of Spills from Aboveground Storage Tanks

- $\quad$ NFPA 30, Flammable and Combustible Liquids Code, 22.11

Equipment, Piping, and Fire Protection Systems in Remote Impoundment Areas and Diked Areas

- $\quad$ NFPA 30, Flammable and Combustible Liquids Code, 22.12

\section{Tank Openings Other than Vents}

- $\quad$ NFPA 30, Flammable and Combustible Liquids Code, 22.13

Aboveground Storage Tanks Located in Areas Subject to Flooding

- NFPA 30, Flammable and Combustible Liquids Code, 22.14

Collision Protection for Aboveground Storage Tanks

- NFPA 30, Flammable and Combustible Liquids Code, 22.15

Installation Instructions for Aboveground Storage Tanks

- NFPA 30, Flammable and Combustible Liquids Code, 22.16

Inspection and Maintenance of Aboveground Storage Tanks

- NFPA 30, Flammable and Combustible Liquids Code, 22.17

- API 653, Tank Inspection, Repair, Alteration, and Reconstruction

- STI SP001, Standard for Inspection of Aboveground Storage Tanks 


\section{Underground Tanks}

Scope

- $\quad$ NFPA 30, Flammable and Combustible Liquids Code, 23.1

\section{Definitions}

- $\quad$ NFPA 30, Flammable and Combustible Liquids Code, 23.2

General Requirements

- $\quad$ NFPA 30, Flammable and Combustible Liquids Code, 23.3

- API, ULC, STI, NACE, and UL Corrosion Protection Standards

- UL, STI and API Underground Tank Specifications

Location of Underground Storage Tanks

- $\quad$ NFPA 30, Flammable and Combustible Liquids Code, 23.4

Installation of Underground Storage Tanks

- NFPA 30, Flammable and Combustible Liquids Code, 23.5

\section{Normal Venting for Underground Storage Tanks}

- $\quad$ NFPA 30, Flammable and Combustible Liquids Code, 23.6

Control of Spills from Underground Storage Tanks

- NFPA 30, Flammable and Combustible Liquids Code, 23.11

\section{Tank Openings Other than Vents}

- NFPA 30, Flammable and Combustible Liquids Code, 23.13

Underground Storage Tanks Located in Areas Subject to Flooding

- NFPA 30, Flammable and Combustible Liquids Code, 23.14

Installation Instructions for Underground Storage Tanks

- NFPA 30, Flammable and Combustible Liquids Code, 23.16

Inspection and Maintenance of Underground Storage Tanks

- NFPA 30, Flammable and Combustible Liquids Code, 23.17

\section{Storage Tank Buildings}

Scope

- $\quad$ NFPA 30, Flammable and Combustible Liquids Code, 24.1

\section{Definitions}

- $\quad$ NFPA 30, Flammable and Combustible Liquids Code, 24.2

\section{General Requirements}

- $\quad$ NFPA 30, Flammable and Combustible Liquids Code, 24.3

\section{Location of Storage Tank Buildings}

- 24.4 NFPA 30, Flammable and Combustible Liquids Code

- NFPA 68, Standard on Explosion Protection by Deflagration Venting

- $\quad$ NFPA 30, Flammable and Combustible Liquids Code, 24.5 
- NFPA 220, Standard on Types of Building Construction

- NFPA 101, Life Safety Code

\section{Fire Protection for Storage Tank Buildings}

- $\quad$ NFPA 30, Flammable and Combustible Liquids Code, 24.6

- NFPA 10, Standard for Portable Fire Extinguishers

- NFPA 13, Standard for the Installation of Sprinkler Systems

- NFPA 14, Standard for the Installation of Standpipe and Hose Systems

- $\quad$ NFPA 24, Standard for the Installation of Private Fire Service Mains and Their Appurtenances

- NFPA $11,12,12 \mathrm{~A}, 15,16,17$, and 25

Emergency Control Systems for Storage Tank Buildings

- $\quad$ NFPA 30, Flammable and Combustible Liquids Code, 24.7

Electrical Systems for Storage Tank Buildings

- $\quad$ NFPA 30, Flammable and Combustible Liquids Code, 24.8

Containment, Drainage, and Spill Control from Storage Tank Buildings

- $\quad$ NFPA 30, Flammable and Combustible Liquids Code, 24.9

\section{Ventilation for Storage Tank Buildings}

- NFPA 30, Flammable and Combustible Liquids Code, 24.10

- NFPA 91, Standard for Exhaust Systems for Air Conveying of Vapors, Gases, Mists, and Noncombustible Particulate Solids

- NFPA 90A, Standard for the Installation of Air-Conditioning and Ventilation Systems

\section{Explosion Control}

- $\quad$ NFPA 30, Flammable and Combustible Liquids Code, 24.12

- NFPA 13, Standard for the Installation of Sprinkler Systems

- NFPA 15, Standard for Water Spray Fixed Systems for Fire Protection

Vents for Tanks Inside Storage Tank Buildings

- NFPA 30, Flammable and Combustible Liquids Code, 24.13

Tank Openings Other than Vents for Tanks Inside Storage Tank Buildings

- NFPA 30, Flammable and Combustible Liquids Code, 24.14

Detection and Alarm Systems for Storage Tank Buildings

- NFPA 30, Flammable and Combustible Liquids Code, 24.15

Inspection of Maintenance for Storage Tank Buildings

- $\quad$ NFPA 30, Flammable and Combustible Liquids Code, 24.16 


\section{Storage Tank Vaults}

Scope

- $\quad$ NFPA 30, Flammable and Combustible Liquids Code, 25.1

\section{Definitions}

- $\quad$ NFPA 30, Flammable and Combustible Liquids Code, 25.2

\section{General Requirements}

- $\quad$ NFPA 30, Flammable and Combustible Liquids Code, 25.3

- ANSI/UL 2245, Standard for Below-Grade Vaults for Flammable Liquid Storage Tanks

\section{Location of Storage Tank Vaults}

- NFPA 30, Flammable and Combustible Liquids Code, 25.4

Construction and Installation of Storage Tank Vaults

- NFPA 30, Flammable and Combustible Liquids Code, 25.5

\section{Fire Protection for Storage Tank Vaults}

- NFPA 30, Flammable and Combustible Liquids Code, 25.6

Emergency Controls For Storage Tank Vaults

- NFPA 30, Flammable and Combustible Liquids Code, 25.7

\section{Electrical Systems for Storage Tank Vaults}

- $\quad$ NFPA 30, Flammable and Combustible Liquids Code, 25.8

Containment, Drainage, and Spill Control for Storage Tank Vaults

- $\quad$ NFPA 30, Flammable and Combustible Liquids Code, 25.9

\section{Ventilation Systems for Storage Tank Vaults}

- NFPA 30, Flammable and Combustible Liquids Code, 25.10

- NFPA 91, Standard for Exhaust Systems for Air Conveying of Vapors, Gases, Mists, and Noncombustible Particulate Solids

\section{Explosion Control}

- NFPA 30, Flammable and Combustible Liquids Code, 25.12

Vents for Tanks Inside Storage Tank Vaults

- NFPA 30, Flammable and Combustible Liquids Code, 25.13

Tank Openings Other than Vents for Tanks Inside Storage Tank Vaults

- NFPA 30, Flammable and Combustible Liquids Code, 25.14

Detection and Alarm Systems for Storage Tank Vaults

- NFPA 30, Flammable and Combustible Liquids Code, 25.15

Inspection and Maintenance of Storage Tank Vaults and Equipment

- NFPA 30, Flammable and Combustible Liquids Code, 25.16 


\section{Processing Facilities}

\section{Scope}

- NFPA 30, Flammable and Combustible Liquids Code, 17.1

\section{Definitions}

- NFPA 30, Flammable and Combustible Liquids Code, 17.2

\section{General Requirements}

- NFPA 30, Flammable and Combustible Liquids Code, 17.3

\section{Location of Process Vessels and Equipment}

- NFPA 30, Flammable and Combustible Liquids Code, 17.4

\section{Accessibility}

- NFPA 30, Flammable and Combustible Liquids Code, 17.5

\section{Construction Requirements}

- NFPA 30, Flammable and Combustible Liquids Code, 17.6

- NFPA 5000, Building Construction and Safety Code

- ICC International Building Code

- NFPA 15, Standard for Water Spray Fixed Systems for Fire Protection

- API 2218, Fireproofing Practices in Petroleum and Petrochemical Processing Plants

- NFPA 204, Standard for Smoke and Heat Venting

- NFPA 101, Life Safety Code

- NFPA 68, Standard on Explosion Protection by Deflagration Venting

\section{Containment, Drainage, and Spill Control}

- NFPA 30, Flammable and Combustible Liquids Code, 17.10

- NFPA 15, Standard for Water Spray Fixed Systems for Fire Protection

\section{Ventilation}

- NFPA 30, Flammable and Combustible Liquids Code, 17.11

- NFPA 91, Standard for Exhaust Systems for Air Conveying of Vapors, Gases, Mists, and Noncombustible Particulate Solids

- NFPA 90A, Standard for the Installation of Air-Conditioning and Ventilation Systems

\section{Process Equipment and Vessels}

- $\quad$ NFPA 30, Flammable and Combustible Liquids Code, 17.14

- NFPA 68, Standard on Explosion Protection by Deflagration Venting

\section{Management of Operations Hazards}

- NFPA 30, Flammable and Combustible Liquids Code, 17.15 


\section{Dispensing, Handling, Transfer, and Use of Liquids}

\section{Scope}

- $\quad$ NFPA 30A, Code for Motor Fuel Dispensing and Repair Garages, 6.1

- NFPA 30, Flammable and Combustible Liquids Code, 18.1

\section{Definitions}

- NFPA 30, Flammable and Combustible Liquids Code, 18.2

\section{General Requirements}

- NFPA 30A, Code for Motor Fuel Dispensing and Repair Garages, 6.2

\section{Requirements for Dispensing Devices}

- NFPA 30A, Code for Motor Fuel Dispensing and Repair Garages, 6.3

\section{Requirements for Remote/Submersible Pumps}

- NFPA 30A, Code for Motor Fuel Dispensing and Repair Garages, 6.4

\section{Requirements for Dispensing Hose}

- NFPA 30A, Code for Motor Fuel Dispensing and Repair Garages, 6.5

\section{Requirements for Fuel Delivery Nozzles}

- NFPA 30A, Code for Motor Fuel Dispensing and Repair Garages, 6.6

- UL 842, Standard for Valves for Flammable Fluids

\section{Emergency Electrical Disconnects}

- NFPA 30A, Code for Motor Fuel Dispensing and Repair Garages, 6.7

\section{Vapor Recovery Systems}

- $\quad$ NFPA 30A, Code for Motor Fuel Dispensing and Repair Garages, 6.8

\section{Dispensing, Handling, Transfer, and Use of Liquids}

- NFPA 30, Flammable and Combustible Liquids Code, 18.3

\section{Incidental Operations}

- NFPA 30, Flammable and Combustible Liquids Code, 18.4

- NFPA 91, Standard for Exhaust Systems for Air Conveying of Vapors, Gases, Mists, and Noncombustible Particulate Solids

\section{Ventilation for Dispensing Areas}

- NFPA 30, Flammable and Combustible Liquids Code, 18.5

- NFPA 91, Standard for Exhaust Systems for Air Conveying of Vapors, Gases, Mists, and Noncombustible Particulate Solids

\section{Component Standards}

- ANSI/UL 25, Meters for Flammable and Combustible Liquids

- ANSI/UL 79, Flammable and Combustible Liquid Pumps for dispensing

- UL 87, Power-Operated Dispensing Devices for Petroleum Products

- UL 330, Hose and Hose Assemblies for Dispensing Flammable Liquids 
- ANSI/UL 331, Strainers for Flammable Fluids and Anhydrous Ammonia

- UL 429, Electrical Valves, for use in control of dispensing equipment

- ANSI/UL 567, Emergency Breakaway Fittings, Swivel Connectors and Pipe-Connection Fittings for Petroleum Products and LP-Gas

- $\quad$ ANSI/UL 842, Valves for Flammable Fluids

- UL 860, Pipe Unions for Flammable and Combustible Fluids and Fire-Protection Service

\section{Operational Requirements}

\section{Scope}

- $\quad$ NFPA 30A, Code for Motor Fuel Dispensing and Repair Garages, 9.1

\section{Basic Requirements}

- $\quad$ NFPA 30A, Code for Motor Fuel Dispensing and Repair Garages, 9.2

- NFPA 385, Standard for Tank Vehicles for Flammable and Combustible Liquids

- NFPA 10, Standard for Portable Fire Extinguishers

\section{Operating Requirements for Full-Service Motor Fuel Dispensing Facilities}

- $\quad$ NFPA 30A, Code for Motor Fuel Dispensing and Repair Garages, 9.3

\section{Operating Requirements for Attended Self-Service Motor Fuel Dispensing Facilities}

- $\quad$ NFPA 30A, Code for Motor Fuel Dispensing and Repair Garages, 9.4

\section{Operating Requirement for Unattended Self-Service Motor Fuel Dispensing} Facilities

- $\quad$ NFPA 30A, Code for Motor Fuel Dispensing and Repair Garages, 9.5

\section{Refueling from Tank Vehicles}

- $\quad$ NFPA 30A, Code for Motor Fuel Dispensing and Repair Garages, 9.6

- NFPA 385, Standard for Tank Vehicles for Flammable and Combustible Liquids

\section{Repair Areas}

- $\quad$ NFPA 30A, Code for Motor Fuel Dispensing and Repair Garages, 9.7

- NFPA 51B, Standard for Fire Prevention During Welding, Cutting, and Other Hot Work

- NFPA 51, Standard for the Design and Installation of Oxygen-Fuel Gas Systems for Welding, Cutting, and Allied Processes

- NFPA 33, Standards for Spray Applications Using Flammable or Combustible Materials

- NFPA 326, Standard for the Safeguarding of Tanks and Containers for Entry, Cleaning, or Repair

- NFPA 31, Standards for the Installation of Oil-Burning Equipment

- NFPA 54, National Fuel Gas Code 
- NFPA 85, Boiler and Combustion Systems Hazards Code

- NFPA 55, Compressed Gases and Cryogenic Fluids Code

\section{Piping for Liquids}

\section{Scope}

- $\quad$ NFPA 30A, Code for Motor Fuel Dispensing and Repair Garages, 5.1

- NFPA 30, Flammable and Combustible Liquids Code, 27.1

\section{Definitions}

- NFPA 30, Flammable and Combustible Liquids Code, 27.2

\section{General Requirements for All Piping Systems}

- $\quad$ NFPA 30A, Code for Motor Fuel Dispensing and Repair Garages, 5.2

- $\quad$ NFPA 30, Flammable and Combustible Liquids Code, 27.3

- ASME B31, Code for Pressure Piping

- API 607, Fire Test for Soft-Seated Quarter-Turn Valves

- ASTM Piping Standards

\section{Materials of Construction for Piping Systems}

- NFPA 30, Flammable and Combustible Liquids Code, 27.4

\section{Pipe Joints}

- NFPA 30, Flammable and Combustible Liquids Code, 27.5

\section{Installation of Piping Systems}

- $\quad$ NFPA 30A, Code for Motor Fuel Dispensing and Repair Garages, 5.3

- $\quad$ NFPA 30, Flammable and Combustible Liquids Code, 27.6

\section{Testing of Piping Systems}

- NFPA 30A, Code for Motor Fuel Dispensing and Repair Garages, 5.4

- $\quad$ NFPA 30, Flammable and Combustible Liquids Code, 27.7

\section{Detector Maintenance}

- NFPA 30A, Code for Motor Fuel Dispensing and Repair Garages, 5.5

\section{Vent Piping}

- $\quad$ NFPA 30A, Code for Motor Fuel Dispensing and Repair Garages, 5.6

- $\quad$ NFPA 30, Flammable and Combustible Liquids Code, 27.8

\section{Vapor Recovery Piping}

- $\quad$ NFPA 30A, Code for Motor Fuel Dispensing and Repair Garages, 5.7

\section{Bonding and Grounding}

- NFPA 30, Flammable and Combustible Liquids Code, 27.9

\section{Identification and Marking of Piping Systems}

- NFPA 30, Flammable and Combustible Liquids Code, 27.10 


\section{Removal From Service of Piping Systems}

- $\quad$ NFPA 30, Flammable and Combustible Liquids Code, 27.12

\section{Vapor Processing and Vapor Recovery Systems for Liquid Motor Fuels}

Vapor Processing Systems

- NFPA 30A, Code for Motor Fuel Dispensing and Repair Garages, 10.1

Vapor Recovery Systems

- NFPA 30A, Code for Motor Fuel Dispensing and Repair Garages, 10.2

\section{Farms and Remote Sites}

\section{Scope}

- $\quad$ NFPA 30A, Code for Motor Fuel Dispensing and Repair Garages, 13.1

- NFPA 30, Flammable and Combustible Liquids Code

\section{Approved Storage}

- $\quad$ NFPA 30A, Code for Motor Fuel Dispensing and Repair Garages, 13.2

- NFPA 30, Flammable and Combustible Liquids Code

\section{Marking of Tanks and Containers}

- NFPA 30A, Code for Motor Fuel Dispensing and Repair Garages, 13.3

\section{Fire Prevention and Control}

- $\quad$ NFPA 30A, Code for Motor Fuel Dispensing and Repair Garages, 13.4

\section{Vehicle}

Fuels

- ASTM D4814-07, Standard Specification for Automotive Spark-Ignition Engine Fuel (E10)

- ASTM D5798-06, Standard Specification for Fuel Ethanol (ED75-Ed85) for Automotive Spark-Ignition Engines (E85)

- ASTM D4806-06c, Standard Specification for Denatured Fuel Ethanol for Blending with Gasolines for Use as Automotive Spark-Ignition Engine Fuel

\section{Systems}

- SAE J30, Fuel and Oil Hoses

- SAE J254, Instrumentation and Techniques for Exhaust Gas Emissions Measurement

- $\quad$ SAE J312, Automotive Gasolines

- SAE J313, Diesel Fuels

- SAE J607, Small Spark Ignition Engine Test Code 
- SAE J905, Fuel Filter Test Methods

- SAE J1082, Fuel Economy Measurement-Road Test Procedure

- SAE J1088, Test Procedure for the Measurement of Exhaust Emissions from Small Utility Engines

- SAE J1094, Constant Volume Sampler System for Exhaust Emissions Measurement

- SAE J1130, Determination of Emission from Gas Turbine Powered light Duty Surface Vehicles

- SAE J1256, Fuel Economy Measurement- Road Test Procedure- Cold Start and Warmup Fuel Economy

- SAE J1297, Alternative Automotive Fuels

- SAE J1312, Procedure for Mapping Engine Performance- Diesel and Spark Ignition Engines

- SAE J1349, Engine Power Test Code- Spark ignition and Diesel

- SAE J1350, Selection and Application Guidelines for Diesel, Gasoline, and Propane Fired Liquid Cooled Engine Pre-Heaters

- SAE J1376, Fuel Economy Measurement Test (Engineering Type) for Trucks and Buses

- SAE J1498, Heating Values of Fuels

- SAE J1829, Stoichiometric Ait/Fuel Ratios of Automotive Fuels

- $\quad$ SAE J2785, Standardization of Color and Verbiage for Fuel Inlet Closures

- SAE J2793, Fuel Dispensing Filter Test Methods- Draft document 